\title{
RESEARCH OF CONSUMER PROPERTIES OF DEVELOPED BISCUITS BASED ON ORGANIC RAW MATERIALS
}

\author{
Alina Tkachenko \\ PhD, Associate Professor \\ Department of Commodity research of foodstuffs \\ Poltava University of Economics and Trade \\ 3 Kovalia str., Poltava, Ukraine, 36014 \\ ialina_biaf@ukr.net \\ Ivan Syrokhman \\ Doctor of technical sciences, professor \\ Department of Commodity Science, Technologies and Food Quality Management \\ Lviv University of Trade and Economics \\ 10 T.-Baranovskoho str., Lviv, Ukraine, 79005 \\ syrokhman@ukr.net

\section{Tetyana Lozova} \\ Doctor of technical sciences, Professor \\ Department of Commodity Science, Technologies and Food Quality Management \\ Lviv University of Trade and Economics \\ 10 T.-Baranovskoho str., Lviv, Ukraine, 79005 \\ lozovatm@gmail.com

\section{Nataliya Ofilenko} \\ PhD, Associate Professor \\ Department of Commodity research, biotechnology, examination and customs \\ Poltava University of Economics and Trade \\ 3 Kovalia str., Poltava, Ukraine, 36014 \\ n.ofilenko@gmail.com

\section{Elena Goryachova} \\ PhD, Associate Professor \\ Department of Commodity research, biotechnology, examination and customs \\ Poltava University of Economics and Trade \\ 3 Kovalia str., Poltava, Ukraine, 36014 \\ goryachova0ea@gmail.com

\section{Yevgenia Hmelnitska} \\ PhD, Associate Professor \\ Department of Commodity research, biotechnology, examination and customs \\ Poltava University of Economics and Trade \\ 3 Kovalia str., Poltava, Ukraine, 36014 \\ evghmel37112@gmail.com

\section{Inna Shurduk} \\ PhD, Associate Professor \\ Department of commercial disciplines \\ Poltava cooperative college \\ 9/17 Nebesnoi Sotni str., Poltava, Ukraine, 36000 \\ sinnes2007@gmail.com
}




\begin{abstract}
The article discusses the recipes of new biscuits based on organic raw materials, as well as the results of the study of their quality and safety indicators. The aim of this research is studying the consumer properties of biscuits, developed on the basis of organic raw materials, which will expand the range of organic confectionery products. The main difference between the developed biscuit recipes is that instead of wheat flour buckwheat flour, spelled flour and hemp flour were used, and coconut and maple sugar were used as sweeteners.

To determine the organoleptic characteristics, a 25-point scale was developed, which includes indicators: taste, smell, appearance, crust state, crumb color. On the basis of the carried out organoleptic assessment, it has been established that the developed biscuits have a pleasant taste and good aroma and are highly appreciated by the tasting commission. Physico-chemical characteristics and safety performance of the developed products were within the normal range. Thanks to the use of non-traditional raw materials, the energy value of biscuits was reduced.

On the basis of the obtained data, the expediency of expanding the range of organic confectionery products with new types of biscuits is substantiated.

Keywords: biscuits, organic raw materials, nutritional value, maple sugar, coconut sugar. Nataliya Ofilenko, Elena Goryachova, Yevgenia Hmelnitska, Inna Shurduk
\end{abstract}

\title{
1. Introduction
}

The number of organic consumers is increasing annually. According to marketing research [1], milk and dairy products, meat and meat products, vegetables and fruits, juices, cereals, flour, and flour products are in the greatest demand among organic products. However, a significant problem of the organic market in many countries is that it mainly consists of raw materials rather than finished products. This encourages the development of new products, which include only organic raw materials. There are many studies that prove the benefits of organic products over traditional ones. In the study [2] it is proved that products from organic raw materials contain less toxic elements than traditional ones. In addition to safety indicators, higher nutritional parameters of organic buckwheat and wheat flour are noted compared to traditional [3, 4]. Organic meat and dairy products are proven to contain higher levels of antioxidants, as well as omega-3 fatty acids and lower levels of cadmium and pesticides [5].

The benefits of consuming organic products are proven by a number of clinical studies. Thus, animal experiments show that identically composed feed from organic and traditional raw materials have a different effect on growth and development. Some types of pesticides permitted in traditional agriculture adversely affect the development of children [6]. In a study [7], it is proved that children who ate exclusively organic foods had a lower percentage of allergies. According to data from a study conducted in the Netherlands, children who ate exclusively organic foods under 2 years old had a lower incidence of eczema [8].

The above leads to the expansion of the range of organic products and the study of consumer properties of the developed products, as well as their introduction into production. Based on this, the aim of research is creation and research of new biscuits based on organic raw materials, which will expand the range of organic confectionery products.

\section{Materials and Methods}

In the course of the research, 2 recipes for "Winter pleasure" and "Exotic" biscuits were developed. The composition of "Winter pleasure" biscuit includes the following organic ingredients: buckwheat flour, ground ginger, maple sugar, eggs, mint essence. To prepare the "Exotic" biscuit also used organic raw materials: spelled flour, hemp flour, rosehip powder, coconut sugar, eggs, lemon-based essences. Description of the organoleptic characteristics of the obtained products is given in Table 1.

The development of new products was carried out taking into account the organoleptic characteristics of the product. Since organoleptic properties are especially important for the consumer, they were analyzed first of all. The scale of assessment of organoleptic indicators, primarily aimed at determining the significance of those or other parameters [9]. Thus, the taste, smell, appearance, 
crust color, the crumb state were determined from the organoleptic indices [10]. Evaluation of organoleptic properties was carried out on a 25-point scale developed by the authors (Table 2).

Table 1

Description of organoleptic characteristics of biscuits

\begin{tabular}{ccc}
\hline Name of the indicator & «Winter pleasure» & «Exotic» \\
\hline taste & $\begin{array}{c}\text { Pleasant, with a touch of ginger and mint } \\
\text { smell }\end{array}$ & Pleasant with sour and citrus flavor \\
Peculiar to a biscuit, odorless, mint & Peculiar to a biscuit, without foreign smells \\
crust color & The layers of the correct form, exactly cut off, without damage, the surface is smooth, without \\
cracks or tears & Light brown & Golden
\end{tabular}

From the physicochemical parameters, humidity was determined by drying to constant weight at a temperature of $105^{\circ} \mathrm{C}$ (Fig. 1).

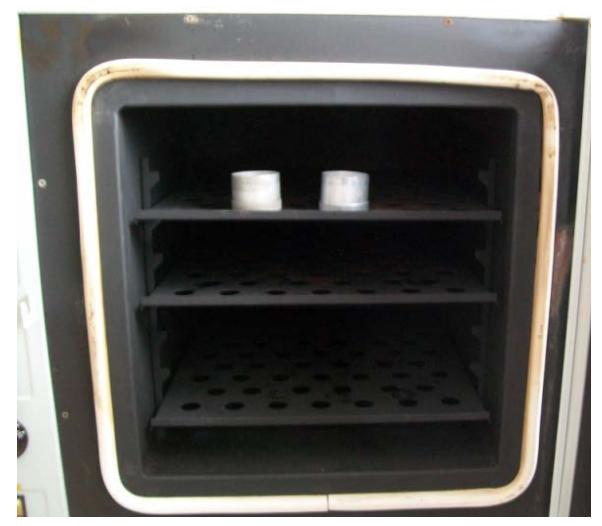

Fig. 1. Drying cabinet for measuring the moisture content of finished products SNOL (Ukraine)

The protein content in the finished products were determined by the Kjedahl method, based on the destruction of organic compounds under the action of boiling sulfuric acid.

Among the safety indicators of finished products, microbiological and toxicological indicators were investigated. To study the content of toxic elements in the finished products, conventional techniques were used: copper, zinc, lead, and cadmium were determined by the atomic absorption method, arsenic by the colorimetric method, and mercury by the flameless atomic absorption method.

Table 2

Biscuit evaluation scale by organoleptic indicators

\begin{tabular}{ccc}
\hline Indicator & Significance coefficient & $\begin{array}{c}\text { Maximum amount of points / Maximum amount of } \\
\text { points, taking into account the coefficient of significance }\end{array}$ \\
\hline Taste & 2 & $5 / 10$ \\
Smell & 2 & $5 / 10$ \\
Appearance & 1 & $5 / 5$ \\
Crust color & 1 & $5 / 5$ \\
Crumb state & 1 & $5 / 5$ \\
Total points & - & 25
\end{tabular}


Mesophilic aerobic and facultative anaerobic microorganisms, CFU in $1 \mathrm{~g}$ was performed using the calculation of colonies, grow on solid nutrient medium after incubation at a temperature of $30{ }^{\circ} \mathrm{C}$ (Fig. 2).

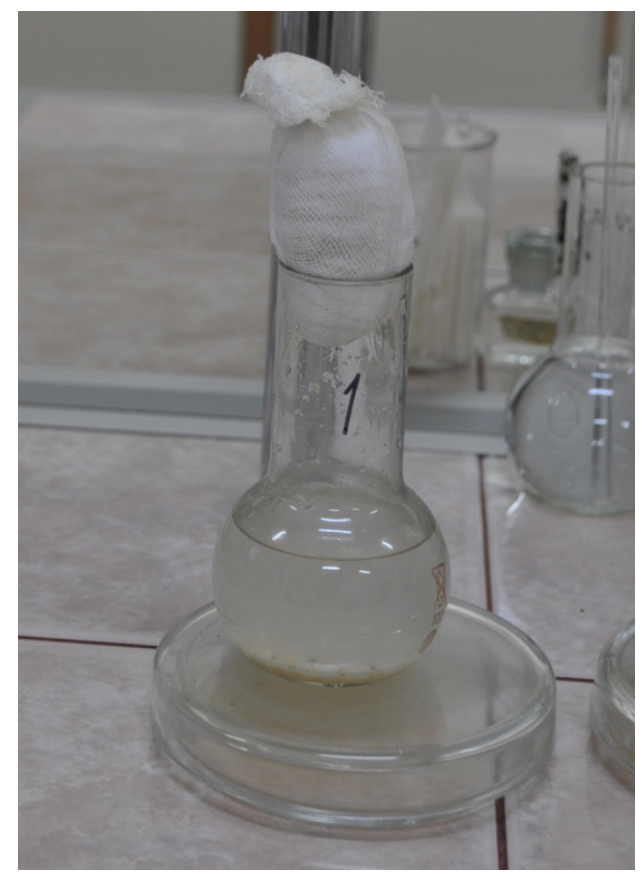

Fig. 2. MAFAM determination

Bacteria of the colibacillus group (coliforms) were determined by the method, which is based on the properties of the bacteria of the colibacillus group to break down glucose and lactose. Pathogenic microorganisms, incl. Salmonella spp. bacteria by the method of identifying Salmonella spp. in food products is based on identifying characteristic growth of colonies on agar differential diagnostic media that have biochemical and serological properties typical of Salmonella spp. bacteria.

\section{Results}

Since organoleptic indicators are the most important for the consumer, first of all, they evaluated the taste, smell, appearance, crumb state and crust color according to the developed 25-point scale. The expert committee consisted of 7 people. The results are presented in Table 3.

Table 3

Evaluation of biscuits by organoleptic characteristics

\begin{tabular}{ccc}
\hline Indicator & «Winter pleasure» & «Exotic» \\
\hline Taste & $5 / 10$ & $5 / 10$ \\
Smell & $5 / 10$ & $5 / 10$ \\
Appearance & 5 & 5 \\
Crust color & 4 & 5 \\
Crumb state & 5 & 5 \\
Indicator & 24 & 25
\end{tabular}


Thus, both samples have high organoleptic characteristics. Thus, the "Winter pleasure" biscuit is rated at 24 points, and Exotic is at 25 . All indicators, with the exception of the crust of the "Winter pleasure" biscuit, are rated with the highest scores.

Humidity in the products was $25 \pm 2 \%$ for the "Winter pleasure" biscuit and $24 \pm 2 \%$ for the semi-finished product "Exotic".

Thanks to the creation of new recipes for biscuits, it is possible to obtain products with improved nutritional value and reduced energy value, which is an important aspect when creating products for dietary purposes. Thus, the amount of proteins is $15.4 \mathrm{~g} / 100 \mathrm{~g}$ for "Winter pleasure" biscuit, $14.4 \mathrm{~g} / 100 \mathrm{~g}$ for "Exotic", the amount of fat is 4.40 and $3.80 \mathrm{~g} / 100 \mathrm{~g}$, the amount of carbohydrates is 50.41 and $55.40 \mathrm{~g} / 100 \mathrm{~g}$. These figures are slightly lower than those of traditional biscuits, which indicate their high nutritional value.

Among the microbiological indicators, MAFAM, bacteria of the colibacillus group and bacteria of the genus Salmonella are investigated. MAFAM content is 100 and $80 \mathrm{CFU}$ in $1 \mathrm{~g}$ for "Winter pleasure" and "Exotic" biscuits, no other microorganisms are found. Toxicological indicators also don't exceed acceptable values.

\section{Conclusions}

On the basis of organoleptic analysis, it is found that the developed recipes for biscuits are distinguished by a pleasant taste and aroma, the "Winter pleasure" biscuit is light brown, and the "Exotic" biscuit is golden in color. The addition of non-traditional raw materials to the composition of biscuits doesn't impair their physico-chemical characteristics. Substitution of sugar for coconut and maple, as well as the use of alternative types of flour lead to a decrease in carbohydrates and energy value in products. Biscuit safety scores were within normal limits. The introduction of the developed biscuits into the production will significantly expand the range of organic flour confectionery products.

Prospects for further research are in conducting a comprehensive assessment of the quality of biscuits, determine the shelf life, the choice of optimal packaging materials and marketing research of the demand for developed products. The main disadvantage of this research is the lack of data on the amino acid, fatty acid and vitamin composition of biscuits. However, the developed formulations can be used by the food industry to expand the range of organic products.

\section{References}

[1] Bryła, P. (2016). Organic food consumption in Poland: Motives and barriers. Appetite, 105, 737-746. doi: https://doi.org/10.1016/j.appet.2016.07.012

[2] Tkachenko, A., Birta, G., Burgu, Y., Floka, L., Kalashnik, O. (2018). Substantiation of the development of formulations for organic cupcakes with an elevated protein content. Eastern-European Journal of Enterprise Technologies, 3 (11 (93)), 51-58. doi: https://doi.org/10.15587/17294061.2018.133705

[3] Krumina-Zemture, G., Ilze, B., Ilze, G. (2016). Amino acid and dietary fiber content of pea and buckwheat flours. Food science, 1, 84-90.

[4] Izembayeva, A. K., Bayisbayeva, M. P., Muldabekova, B. Z. H. (2014). Non-Traditional Raw Materials in Production of Sugar Cookies. American-Eurasian J. Agric. \& Environ. Sci., 3, 358-362.

[5] Barański, M., Rempelos, L., Iversen, P. O., Leifert, C. (2017). Effects of organic food consumption on human health; the jury is still out! Food \& Nutrition Research, 61 (1), 1287333. doi: https:// doi.org/10.1080/16546628.2017.1287333

[6] Mie, A., Andersen, H. R., Gunnarsson, S., Kahl, J., Kesse-Guyot, E., Rembiałkowska, E. et. al. (2017). Human health implications of organic food and organic agriculture: a comprehensive review. Environmental Health, 16 (1). doi: https://doi.org/10.1186/s12940-017-0315-4 
[7] Alfven, T., Braun-Fahrlander, C., Brunekreef, B., Mutius, E., Riedler, J. et. al. (2006). Allergic diseases and atopic sensitization in children related to farming and anthroposophic lifestyle - the PARSIFAL study. Allergy, 61 (4), 414-421. doi: https://doi.org/10.1111/j.1398-9995.2005.00939.x

[8] Kummeling, I., Thijs, C., Huber, M., van de Vijver, L. P. L., Snijders, B. E. P., Penders, J. et. al. (2007). Consumption of organic foods and risk of atopic disease during the first 2 years of life in the Netherlands. British Journal of Nutrition, 99 (03). doi: https://doi.org/10.1017/s0007114507815844

[9] Oleksienko, N., Nedelina, L. (2013). Sensorna otsinka yakosti kondyterskykh vyrobiv u protsesi zberihannya. APK, 5, 22-24.

[10] Rosdima, T. (2015). Sensorniy analiz kak sostavlyayushchaya chast' tovarnoy ekspertizy pishchevykh produktov. Mezhdunarodnaya torgovlya i torgovaya politika, 4 (4), 84-86. 